\title{
NOTÍCIAS BIBLIOGRÁFICAS
}

\section{RECENSO็ES}

MOVIA, Giancarlo. Apparenze Essere e Verità. Commentario storico-filosofico al "Sofista" di Platone. Prefazione di Hans Krämer e Introduzione di Giovanni Reale. Milano: Vita e Pensiero, 1991, p. 537.

Odone José de Quadros*

O autor é professor de História da Filosofia na Universidade de Cagliari. Aqqui apresenta uma detida análise e comentário do diálogo Sofista de Platão. A qualidade de comentarista excele na medida em que faz um debate com todos os principais textos críticos dos últimos decênios sobre o diálogo citado de Platão, em especial, com a Escola de Tübingen. O livro se compõe de três partes, de um capítulo final de conclusões gerais, além de bibliografia e índices, com prefácio de Hans Krämer e introdução de Giovanni Reale. A primeira parte trata da Diairesis e das Idéias-Número. A segunda põe o Sofista dentro da História da Filosofia. A terceira versa sobre a dialética das idéias. Um breve capitulo apresenta as conclusões gerais onde o titulo da obra Apparenze, Essere e Verità se explicita: "Platão conquistou o ponto de vista segundo o qual o não-ser, o falso, o mal, o inconsistente, $\mathrm{e}$ portanto aquilo que não é, também é. Mas, com isto, o sentido do ser dever-se-ia transformar, já que agora o próprio não ser devia, ao mesmo tempo, vir introduzido na essência do ser. Mas se o ser é, desde o principio o Uno ( $\varepsilon v$ ) esta introdução do não-ser na unidade significa o desdobrar-se da unidade na multiplicidade. Mas, com isto, o múltiplo (os muitos) não é mais simplesmente separado do Uno, do único, mas os dois se tornam reconhecidos no seu co-pertencer" (M. Heidegger, Aristoteles, Metaphysik IX, 1 - 3; GA, XXXIII, p. 27 s. Movia, p. 473). A bibliografia, literatura crítica citada e utilizada, é extensa e pormenorizada. Dois índices gerais, um dos nomes dos autores antigos citados; outro, dos nomes dos autores modernos citados, são amplos e demonstrativos da seriedade e riqueza conceitual do trabalho. A obra inteira é trabalhada com a indispensável análise do original grego, a cada passo, referido, com a grafia em caracteres da lingua grega.

A temática do Sofista é apresentada, no seu desenvolvimento e nas suas articulaçōes, à luz de um novo paradigma hermenêutico que leva em conta as doutrinas não escritas e que, por sua vez, remetem à tradição indireta. $\mathrm{O}$ autor faz uma sintese entre as duas tendências opostas descritas. Uma sintese não sincretista, mas por via da mediação do paradigma hermenêutico, com as indicações provenientes das doutrinas não escritas: uma mediação sintética. Propōe, portanto, uma releitura do diálogo como um dos mais ricos diálogos dialéticos. Apresenta a análise do texto do Sofista numa nova ótica: sem descurar das questões ontológicas e metafísicas, empregando os instrumentais lógico-analíticos, costurando o comentário numa perspectiva histórica: esta nova perspectiva configura o "novo paradigma hermenêutico" (MOVIA, p. 22 e p. 31). Por outra parte, a obra se caracte-

* Pontificia Universidade Católica do Rio Grande do Sul, PUCRS.

\begin{tabular}{|l|l|l|l|l|l|} 
VERITAS & Porto Alegre & v. 42 & $\mathrm{n}$ ㅇ 4 & Dezembro 1997 & p. 977-1050 \\
\hline
\end{tabular}


riza por uma rara completude de referências à bibliografia crítica, ou seja, Movia fez seu trabalho após conhecer tudo o que de mais recente se escreveu como literatura crítica sobre o Sofista.

Neste contexto de diálogo com a pesquisa de outros comentaristas, a análise de Movia aparece sempre referenciada a de outros críticos, quer nos momentos mais explícitos do Sofista, nos quais Platão apresenta pontos de vista, bem como quando Platão fala do projeto do "Filósofo", do conceito de "Ser", da "seleção" de Metaidéias; como também quando se trata da doutrina não escrita - quanto às divisões categoriais, reduções categoriais, bipolaridade do princípio de unidade e dualidade, estrutura numérica do âmbito das realidades ideais. Valendo-se, ainda, muitas vezes, do próprio esboço já desenhado por Platão de modo programático no Fedro. O autor comenta o Sofista hoje, com notável gosto "por certas formas de análise do tipo lógico-formal" e com grande interesse "por certas releituras analíticas dos textos dos autores antigos".

O autor, exatamente em razão desta sua ampla perspectiva, consegue ultrapassar a simples análise teórica do texto para alcançar aspectos axiológicos presentes no Sofista, de modo a poder relacioná-lo com os escritos ético-políticos de Platão. Aparece, também, já de início, o progresso apresentado por Movia na compreensão da diairesis (diérese), ponto muitas vezes descurado pela maioria dos críticos, mas sublinhado através de estudos sinópticos pelo autor, no que ele se aproxima, mas de modo autônomo, do trabalho de $\mathrm{M}$. Kranz, 1986, em Tübingen. O autor não descura do "discurso alusivo", a seu parecer, tão presente no Sofista. Quando Platão diz que procurando o "sofista" lhe ocorreu de descobrir "primeiro o filósofo", está fazendo um jogo alusivo (253 C).

A obra discorre sobre o complexo nexo do Uno com os Múltiplos que sustenta a dialética, em todas as suas formas, com a trama matemática que a acompanha. "Portanto, quem é capaz de fazer isto, distingue adequadamente a Idéia que se estende de muitas partes através de muitas outras, cada uma das quais permanece uma unidade separada e, além disso, muitas Idéias diversas entre si, abraçadas desde fora por uma única Idéia; e, por outra parte, uma única Idéia através de muitos inteiros (todos - totalidades) recolhidos na unidade; e, além do mais, muitas Idéias completamente distintas e separadas. $\mathrm{E}$ isto é saber distinguir por gêneros e compreender de que modo cada um pode comunicar e de que modo não" (253 B - $254 \mathrm{~B}$ ).

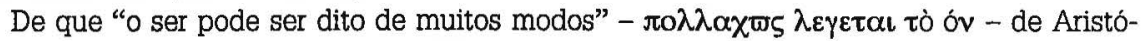
teles tem raiz exatamente neste diálogo, ao mesmo tempo em que Platão comete o "parricídio de Parmênides". Este é o ponto de vista do autor: "[...] Se não se 'mata' Parmênides (ou seja, se ele não é superado de modo estrutural) fica-se bloqueado em uma posição de acomodamento e, no entanto só um 'filho' o pode superar, ou seja, alguém que saiba desfrutar daquilo que é o seu ganho essencial (isto é, que lhe mantenha o sangue). De fato, exatamente enquanto Platão diz que comete o 'parricídio' de Parmênides, Platão nos diz também eo ipso que é seu filho" (Movia, p. 25).

Considera o Sofista não separado, mas no amplo contexto já exposto, o que permite ao autor alcançar uma rara compreensão de que a diairesis "ou seja, o método dialético da divisão, do qual Platão no nosso diálogo faz quase uma orgia báquica (um bacanal), constitui somente uma parte da dialética e esta mesma parte da dialética não vem apresentada na sua inteireza" (Movia, p. 19).

Uma surpresa é a da valorização dada pelo autor à primeira parte do Sofista, onde se apresenta o exemplo da pesca com anzol - aspaliêutica - ou com linha de pesca. Aí é aplicado sete vezes o método da diairesis para se chegar à definição de "sofista". Ambos, o pescador e o sofista, são descritos como "caçadores de presa", "caçadores predadores": o primeiro de peixes, o segundo de homens. 